\title{
Induction of oxidative stress and apoptosis in human neutrophils by $\mathrm{p}$-phenylenediamine
}

\author{
Zineb Elyoussoufi ${ }^{1,2 \star}$, Norddine Habti ${ }^{2}$, Khadija Mounaji ${ }^{1}$, Said Motaouakkil ${ }^{2,3}$ and Rachida \\ Cadi $^{1}$ \\ ${ }^{1}$ Department of Biology, Ain Chock Faculty of Sciences, Laboratory of Physiology and Molecular Genetics, Genetics, \\ associated with CNRST, Hassan II University, Casablanca, Morocco. \\ ${ }^{2}$ Laboratory of Hematology, Experimental Medicine and Biotechnology, associated with CRTS, Faculty of Medicine and \\ Pharmacy, University Hassan II, Casablanca, Morocco. \\ ${ }^{3}$ Medical intensive care unit, Ibn Rochd university hospital, Casablanca, Morocco.
}

Accepted 13 July, 2013

\begin{abstract}
Exposure to paraphenylenediamine (PPD), a derivative of paranitroaniline widely used as an oxidisable hair dye, is often associated with the development of allergic contact dermatitis. Such reactions involve activation of the subject's immune system and it is known that neutrophils are the first cells to arrive at the site of perturbation. In view of its pivotal role in the initiation and amplification of inflammation, the fate of the neutrophil in presence of PPD requires attention. Thus, the purpose of the present study was to evaluate the vitro effects of PPD on human neutrophils viability and on reactive oxygen species production. Neutrophils from healthy volunteers were incubated with three concentrations of PPD (11.5, 23 and $46 \mu \mathrm{M})$. Apoptosis was evaluated by light microscopy and DNA gel electrophoresis, and oxidative stress was evaluated by spectrophotometry. Results showed that PPD induces neutrophils apoptosis in a dose and time dependent manner with a $L^{2} C_{50}$ value of $23 \mu \mathrm{M}$ at $6 \mathrm{~h}$ of treatment. Furthermore, at $5 \mathrm{~h}$ of treatment, PPD markedly increased lipid peroxidation $(47 \%)$ and enhanced the activity of catalase, glutathione reductase and superoxide dismutase. These results suggest that PPD can induce neutrophils apoptosis and an oxidative stress.
\end{abstract}

Key words: Paraphenylenediamine, neutrophils, apoptosis, oxidative stress, catalase, lipid peroxidation, glutathione reductase, superoxide dismutase.

\section{INTRODUCTION}

Paraphenylenediamine (PPD) is the most widely used primary intermediate in hair dye formulations (Corbett and Menkart, 1973). It is also used as photographic developing agent and as an intermediate in the manufacture of azo dyes, antioxidants, and accelerators for rubber vulcanization (Hansen et al., 1993). Human exposure to PPD is almost unavoidable. In fact, PPD is classified as strong and extreme sensitizer. On contact, PPD can produce severe allergic dermatitis (Smith, 2003). Perhaps PPD provides chemical signals that may activate immune cells and act as antigenic stimuli and thereby induce contact dermatitis. The effects of PPD on immune cells are thought to derive from the compound's instability. In fact, PPD is intrinsically unstable under 
aqueous conditions. Auto-oxidation leads to the formation of an electrophilic quinonediimine intermediate which is susceptible to sequential self-conjugation. An end product of these oxidoconjugation reactions is the trimer Bandrowski's base (BB) (Picardo et al., 1990).

Studies have demonstrated that topical exposure of mice to both PPD and BB leads to immune cell activation, as measured by an increased cellular infiltration of draining lymph nodes (Aeby et al., 2004; Warbrick et al., 1999; White et al., 2006). In human volunteers, 50 to $100 \%$ of individuals treated with a topical solution of PPD at concentrations of 1 to $30 \%$ showed evidence of sensitization (Kligman, 1966; Marzulli and Maibach, 1974). Moreover, direct contact with PPD may cause skin irritation, keratoconjunctivitis, swollen conjunctiva and eczema of eye lids (Sax, 1984). Although these data suggest that PPD and BB are immunogenic, the nature of the chemical entity that interacts with immune cells has not been fully elucidated and needs further investigations. Furthermore, previous studies have shown that PPD application induces injury to rat skin (Lee et al., 2002; Mathur et al., 2005). Generally, xenobiotic-induced tissue damage is related to reactive metabolites as well as produced reactive oxygen species (ROS) (Freeman and Crapo, 1982; Mattia et al., 1993).

It is well known that neutrophils play an important role in mediating tissue injury in a wide range of inflammatory diseases. In fact, activated neutrophils can release ROS and proteins that act as mediators of inflammation and induce tissue injury (Ward et al., 1988). In addition, at the inflammatory sites, the expression of neutrophils constitutive cell death program can be delayed or accelerated by a number of agents (Edwards et al., 2004; Scheel-Toellner et al., 2004a). These data promoted us to investigate the effect of PPD on neutrophils. Since the impact of PPD on the ROS pathway in neutrophils has not been studied yet in vitro, the objective of the present study was to evaluate the effects of PPD on human cultured neutrophils viability and to evaluate the implication of oxidative stress in the cytotoxicity of PPD.

\section{MATERIALS AND METHODS}

\section{Isolation of human neutrophils}

Human neutrophils were isolated from peripheral blood of healthy volunteers using a method of density centrifugation and dextran sedimentation. Briefly, human peripheral blood was separated by Ficoll-Hypaque (Eurobio, France). Residual erythrocytes in the polymorphonuclear leukocytes (PMN) pellet were lysed by hypotonic lysis. The cells were re-suspended in RPMI 1640 medium. Neutrophils were counted using a Malassez hemocytometer slide. In all cases, purity was greater than $97 \%$, with viability of neutrophils as assessed by trypan blue exclusion greater than 95\% immediately after purification.

\section{Culture conditions}

Neutrophils were cultured in RPMI 1640 medium supplemented with $100 \mathrm{Ul} / \mathrm{ml}$ penicillin, $0.1 \mathrm{mg} / \mathrm{ml}$ streptomycin and $10 \%$ fetal calf serum. Neutrophils were incubated with or without 11.5, 23 and 46 $\mu \mathrm{M}$ of PPD for 1 to $6 \mathrm{~h}$ at $37^{\circ} \mathrm{C}$ in a $5 \% \mathrm{CO}_{2}$ atmosphere in 96 well plates at a concentration of $1.5 \times 10^{5}$ cells $/ \mathrm{ml}$. Neutrophils cultured with $0.2 \mu \mathrm{M}$ of dexamethasone (Dex) or cultured for $24 \mathrm{~h}$ in medium alone were used as positive control of apoptosis estimation.

\section{Morphological assessment of apoptosis}

Cellular morphology was ascertained by light microscopy following May-Grunwald-Giemsa (MGG) staining of cytocentrifuged cells. Cytospins were prepared using a Shandon cytospin2. Cells were assessed for morphological changes characteristic of apoptosis. At least 300 cells per slide were counted.

\section{DNA fragmentation assay}

DNA was extracted from washed PMN by phenol-chloroform method. Briefly, $1.5 \times 10^{5}$ cells were lysed. DNA was extracted with equal volume of phenol-chloroform-isoamylalcohool (25/24/1), precipitated with absolute ethanol and suspended in Tris-EDTA buffer. The DNA samples $(0.25 \mu \mathrm{g}$ of DNA) were analyzed by gel electrophoresis ( $2 \%$ agarose). Protein concentrations were determined by the Bradford method using bovin serum albumin (BSA) as a standard (Bradford, 1976).

\section{Evaluation of lipid peroxidation}

Lipid peroxidation was estimated by thiobarbituric acid reactive substances (TBARS) reaction with malondialdehyde (MDA) as described by Samokyszyn and Marnett (1990). Briefly, $100 \mu \mathrm{l}$ of protein extract were added to $15 \%$ trichloroacetic acid (TCA), $0.375 \%$ TBA and $0.25 \mathrm{M} \mathrm{HCl}$. The absorbance of the supernatant was read at $535 \mathrm{~nm}$. The MDA level was expressed as $\mathrm{nmol} / \mathrm{min} / \mathrm{mg}$ protein.

\section{The catalase (CAT) activity}

Catalase activity was measured according to Aebi (1984). The specific activity is given as nanomoles of consumed $\mathrm{H}_{2} \mathrm{O}_{2} / \mathrm{min} / \mathrm{mg}$ protein using molar extinction coefficient of $40 \mathrm{M}^{-1} \mathrm{~cm}^{-1}$.

\section{Glutathione reductase (GR) activity}

To estimate the GR activity, the method of DI HIO et al. (1983) was used. The enzyme activity was calculated as nanomoles of nicotinamide adenine dinucleotide phosphate (NADPH) oxidized $/ \mathrm{min} / \mathrm{mg}$ protein using molar extinction coefficient of $6220 \mathrm{M}^{-1} \mathrm{~cm}^{-1}$.

\section{Superoxide dismutase (SOD) activity}

The SOD activity was measured according to Paoletti et al. (1986). The enzyme activity was expressed as $\mathrm{nmol} / \mathrm{min} / \mathrm{mg}$ protein using molar extinction coefficient of $6220 \mathrm{M}^{-1} \mathrm{~cm}^{-1}$.

\section{Statistical analysis}

All experiments were repeated at least three times. The data 


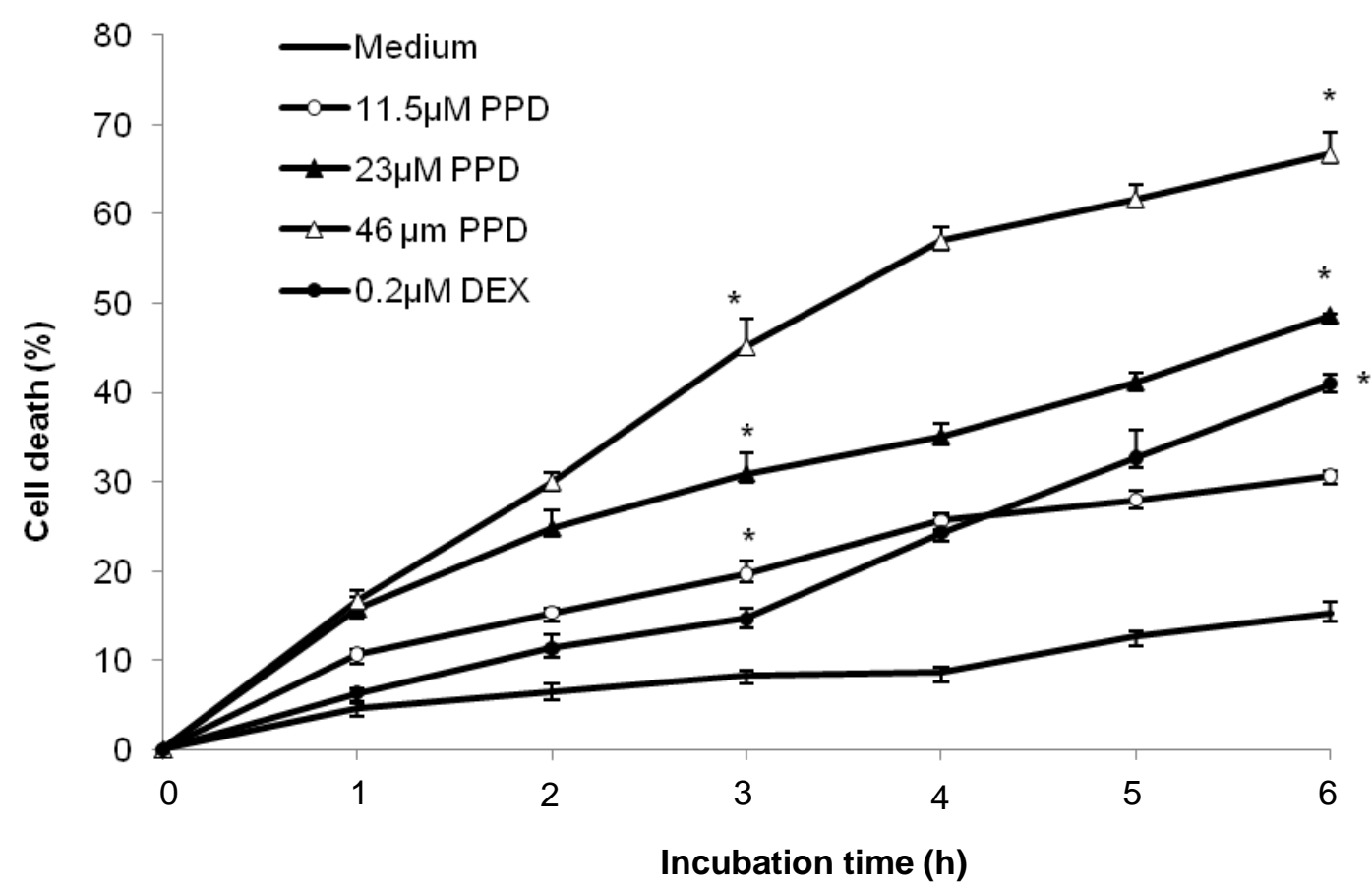

Figure 1. Time course of the viability of neutrophils after treatment with PPD. Cells were treated with $11.5,23$ and $46 \mu \mathrm{M}$ of PPD for 1 to $6 \mathrm{~h}$. Results are shown as mean \pm SEM from three independent experiments. ${ }^{*} \mathrm{p}<0.003$.

obtained were analyzed using the Student's t-test. Results were expressed as the mean \pm standard error of mean (SEM). Significant difference was taken as $p<0.05$.

\section{RESULTS}

\section{PPD induces cytotoxicity in human cultured neutrophils in a time and dose dependent manner}

To determine the effect of PPD on human neutrophils viability, freshly isolated PMN cells were cultured with increasing dose of PPD 11.5, 23 and $46 \mu \mathrm{M}$ for 1 to $6 \mathrm{~h}$, then cell viability was evaluated by trypan blue dye exclusion method. Cells cultured with $0.2 \mu \mathrm{M}$ of Dex were used as control. Results revealed that PPD treatment increases neutrophils cell death in a dose dependent manner. As shown in Figure 1, at $3 \mathrm{~h}$, cell death was 21, 30,45 and $15 \%$ in cells treated, respectively with 11.5 , 23, $46 \mu \mathrm{M}$ of PPD and $0.2 \mu \mathrm{M}$ Dex compared to untreated cells $(8 \%)(p \leq 0.003)$. Results showed also that PPD increased neutrophil cell death time dependently. A dose of $23 \mu \mathrm{M}$ enhanced cell death to 25 , 35 and $49 \%$ at 2,4 and $6 h$, respectively $(p<0.003$ ) (Figure 1). A LC 50 value was noted approximately at $3 \mathrm{~h}$ with $46 \mu \mathrm{M}$ and at $6 \mathrm{~h}$ with $23 \mu \mathrm{M}$ PPD. In order to expend knowledge about the mechanism inducing the
PPD cytotoxicity, $23 \mu \mathrm{M}$ PPD was selected to continue the following experiments and cells were cultured till $5 \mathrm{~h}$ instead of $6 \mathrm{~h}$.

\section{PPD affected cell morphology of human neutrophils}

To determine which cell death type results of PPD toxicity in human cultured neutrophils, cells were incubated with $23 \mu \mathrm{M}$ of PPD for $5 \mathrm{~h}$ and the morphology was examined using (MGG) staining. Cells cultured with $0.2 \mu \mathrm{M}$ of Dex or cultured for $24 \mathrm{~h}$ in medium alone were used as control of apoptosis. On light microscopy, $40 \%$ of neutrophils treated with $23 \mu \mathrm{M}$ PPD were showing morphological changes such as loss of multilobular nuclear structure, a nuclear pyknosis and cellular shrinkage (Figure 2B). The same changes were observed in $33 \%$ of cells treated with $0.2 \mu \mathrm{M}$ Dex (Figure $2 \mathrm{C}$ ) and in $47 \%$ of cells cultured for $24 \mathrm{~h}$ in medium alone (data not shown). While only $13 \%$ of untreated neutrophils showed changes in their morphology at $5 \mathrm{~h}$ of culture (Figure $2 \mathrm{~A}$ ).

\section{PPD induces human neutrophils apoptosis}

As shown in Figure 2, neutrophils treated with $23 \mu \mathrm{M}$ PPD exhibit morphological features of apoptosis. The 

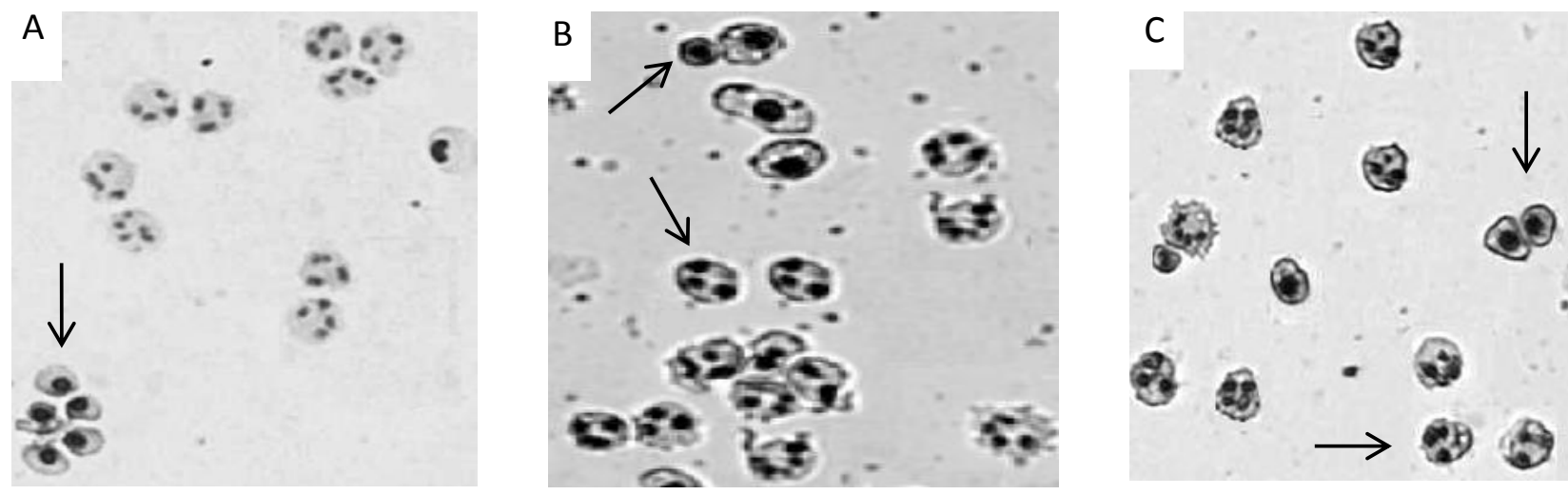

Figure 2. Light microscopy of cultured neutrophils. Cytospin slides preparations of neutrophils were stained with MGG and apoptotic cells ( arrows) wer $\$$ evaluated morphologically. The micrographs show neutrophils $(\times 400)$ treated for $5 \mathrm{~h}$ as follows: A) incubated in medium alone; B) treated with $23 \mu \mathrm{M}$ of PPD and C) treated with $0.2 \mu \mathrm{M}$ of Dex.

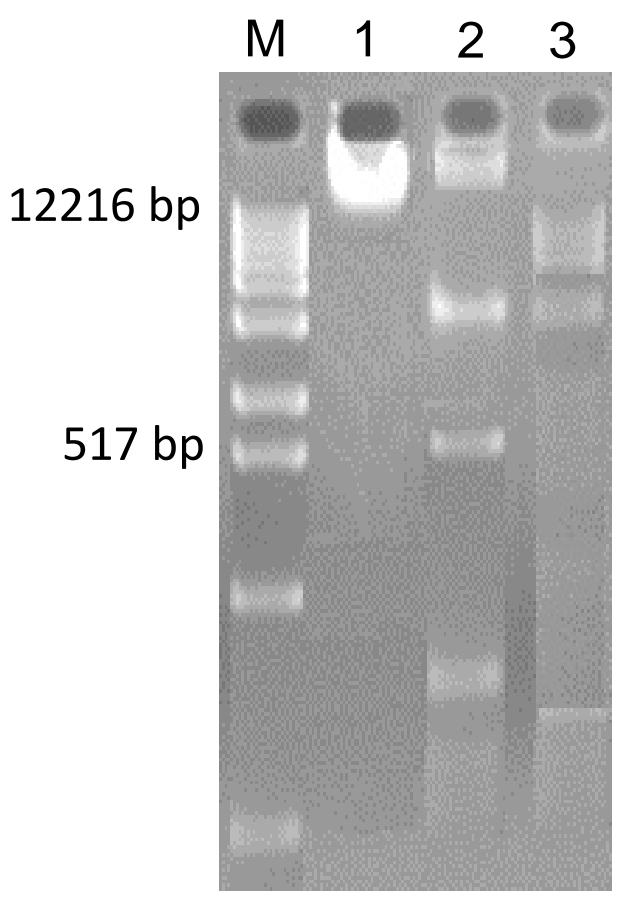

Figure 3. Effect of PPD in DNA fragmentation in neutrophils. Cells were cultured for $5 \mathrm{~h}$ : lane 1: in medium alone, lane 2: in $23 \mu \mathrm{M}$ of PPD and lane 3: in $0.2 \mu \mathrm{M}$ of Dex. The molecular size markers are indicated on the left, lane $M$.

appearance of such apoptotic cells was also evidenced by DNA fragmentation analysis (Figure 3). DNA from human neutrophils treated with $23 \mu \mathrm{M}$ of PPD or $0.2 \mu \mathrm{M}$ of Dex for $5 \mathrm{~h}$ was extracted and subjected to agarose gel electrophoresis. PPD induced DNA fragmentation was evidenced by DNA laddering after $5 \mathrm{~h}$ of incubation (Figure 3).

\section{The PPD effect on lipid peroxidation in human neutrophils}

Since PPD has been shown to trigger production of ROS, we next assayed for PPD induced production of ROS in human cultured neutrophils. PMN cells were treated with $23 \mu \mathrm{M}$ PPD or $0.2 \mu \mathrm{M}$ Dex for 2, 3 and $5 \mathrm{~h}$. Lipid peroxidation was assessed by spectrophotometry. As shown in Figure 4, the MDA levels increased in a time dependent manner in both PPD and Dex treated cells ( $p$ $<0.05$ ). Furthermore, at $5 \mathrm{~h}$ it is increased even in untreated cells $(p=0.02)$. On top of that, PPD appear to markedly affect the MDA levels. For example, at $5 \mathrm{~h}$, the MDA level increased by a factor of about 1.9 to reach 71 $\mathrm{nmol} / \mathrm{min} / \mathrm{mg}$ protein in PPD treated cells compared to 38 $\mathrm{nmol} / \mathrm{min} / \mathrm{mg}$ protein in untreated cells $(\mathrm{p}=0.006)$ (Figure 4).

\section{The effect of PPD in ROS scavenging enzymes}

Enzyme activities of (CAT), (GR) and (SOD) in human neutrophils treated with $23 \mu \mathrm{M}$ PPD or $0.2 \mu \mathrm{M}$ Dex for 2 , 3 and $5 \mathrm{~h}$ are shown in Figure 5A, B and C. No significant changes were observed in the CAT activity before $5 \mathrm{~h}$ (Figure $5 \mathrm{~A}$ ). At $5 \mathrm{~h}$, compared to $2 \mathrm{~h}$, it is significantly enhanced by a factor of about 2.8, 5.5 and 4.2 in respectively untreated, Dex treated and PPD treated cells $(p \leq 0.02)$. Moreover, at the same time, the CAT activity was more important in PPD treated cells (132 $\mathrm{nmol} / \mathrm{min} / \mathrm{mg}$ protein) and Dex treated cells (101 $\mathrm{nmol} / \mathrm{min} / \mathrm{mg}$ protein) than untreated cells $(71 \mathrm{nmol} / \mathrm{min} / \mathrm{mg}$ 


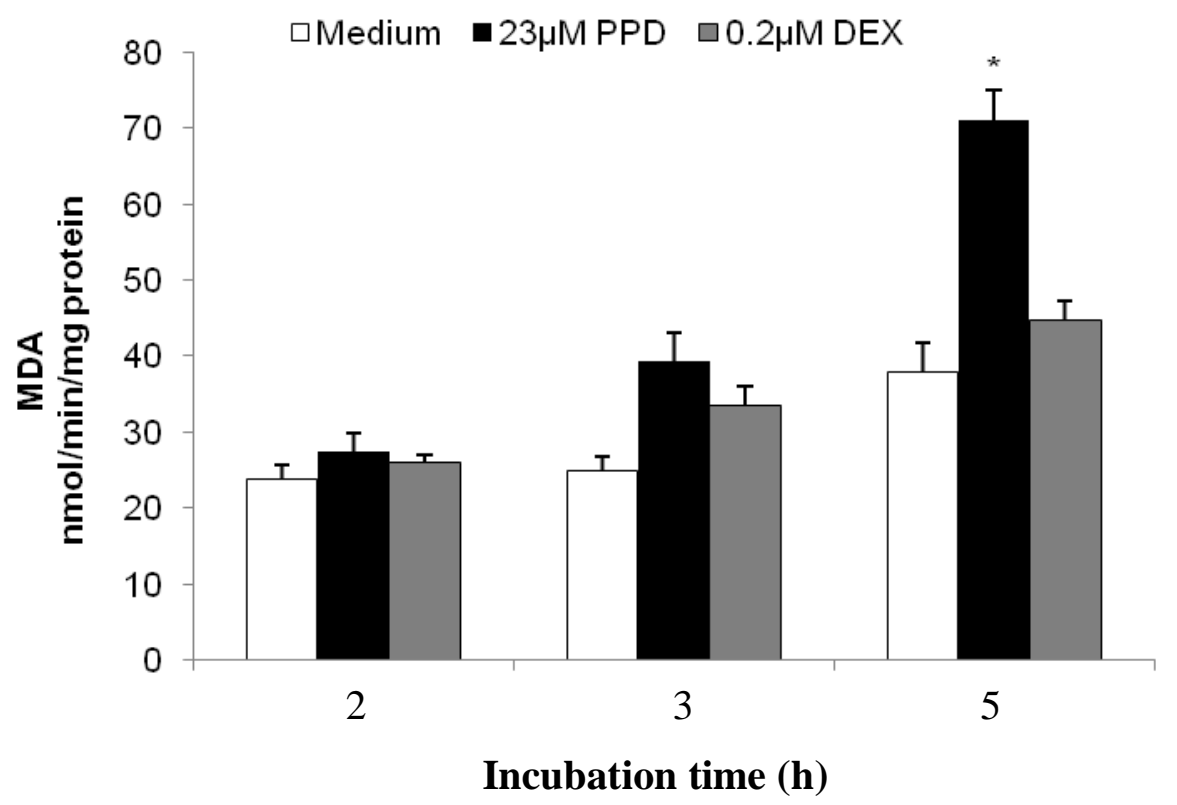

Figure 4. Lipid peroxidation in human neutrophils. Cells were treated with $23 \mu \mathrm{M}$ of PPD or $0.2 \mu \mathrm{M}$ of Dex for 2,3 and $5 \mathrm{~h}$. Results are shown as mean \pm SEM from three independent experiments. ${ }^{*} \mathrm{p}=0.006$.

protein) ( $p=0.0006$ and $p=0.02$, respectively) (Figure $5 A)$. As shown in Figure 5B, the GR activity increased in a time dependent manner in both PPD and Dex treated cells $(p<0.05)$, while in untreated cells, it only increased at $3 \mathrm{~h}(\mathrm{p}<0.001)$. PPD increased the GR activity by a factor of about 1.6 and 2.0 at respectively 3 and $5 \mathrm{~h}$ compared to untreated cells $(p<0.001)$. At the same time, Dex seems to increase the GR activity by 1.1 and $1.5(p=0.03)$ (Figure 5B). The SOD activity increased in time dependent manner in treated and untreated cells ( $p$ $\leq 0.01$ ) (Figure $5 \mathrm{C}$ ). After $2 \mathrm{~h}$, both PPD and Dex markedly increased the SOD activity by a factor more than 1.5 compared to untreated cells $(p \leq 0.02)$. The highest levels were noted at $5 \mathrm{~h}$ of treatment (2.074 $\mathrm{nmol} / \mathrm{min} / \mathrm{mg}$ protein) and (1.897 $\mathrm{nmol} / \mathrm{min} / \mathrm{mg}$ protein), respectively in cells treated with $23 \mu \mathrm{M}$ PPD and $0.2 \mu \mathrm{M}$ Dex compared to untreated cells $(0.846 \mathrm{nmol} / \mathrm{min} / \mathrm{mg}$ protein) ( $p=0.001$ and $p=0.008$, respectively) (Figure $5 \mathrm{C})$.

\section{DISCUSSION}

PPD is an aromatic amine found in dark blue and black clothing dyes, so virtually everyone is exposed to contact with PPD (Coulter et al., 2008). Exposure to PPD is often associated with the development of allergic contact dermatitis and inflammation (Smith, 2003). It is known that neutrophils are the first cells to arrive at the site of perturbation, and subsequent or accompanying inflammatory events may depend on this initial neutrophil accumulation (Doherty et al., 1988; Wedmore and Williams, 1981). In view of its important role in the initiation and amplification of inflammation, the fate of the neutrophil in presence of PPD requires attention. Thus, we investigated here the effect of PPD on neutrophils viability.

The present study shows that PPD induces cytotoxicity in human cultured neutrophils in a dose and time dependent manner. This cytotoxicity was expressed by high levels of cell death with $\mathrm{LC}_{50}$ value of $23 \mu \mathrm{M}$ at $6 \mathrm{~h}$. A similar toxic effect was observed in Mardin-Darby canine kidney (MDCK) cells after $12 \mathrm{~h}$ of treatment with $37.5 \mu \mathrm{g} / \mathrm{ml}$ of PPD (Chen et al., 2010). Furthermore, Coulter et al. (2007) have found an increase in cell death when human dendritic cells were incubated with $250 \mu \mathrm{M}$ of PPD for $16 \mathrm{~h}$. To confirm the cytotoxicity of PPD, neutrophils were treated and observed microscopically. We have detected specific changes in the morphology of treated neutrophils including nuclear pyknosis and chromatin condensation. These modifications were characteristic of apoptosis (Wyllie, 1980). This finding was evidenced by DNA fragmentation analysis in agarose gel electrophoresis. These results are in concordance with those found in human urothelial cells and lymphocytes (Huang et al., 2007; Chye et al., 2008).

Next, we focused our effort on answering if the damage observed on neutrophils were accompanied or induced 

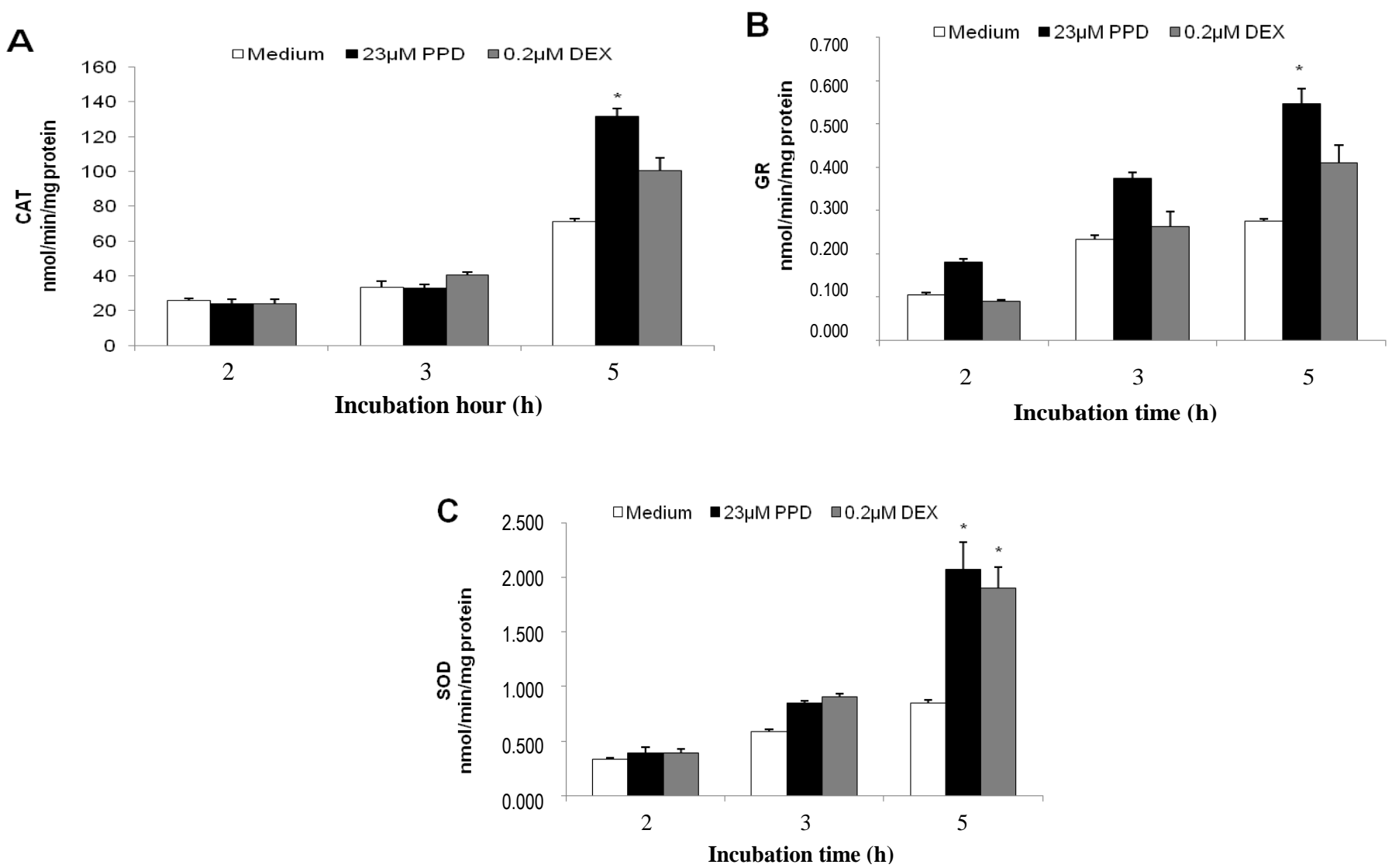

Figure 5. Antioxidant enzymes activities in human neutrophils. A) CAT activity. B) GR activity and C) SOD activity. Cells were treated with $23 \mu \mathrm{M}$ of PPD or $0.2 \mu \mathrm{M}$ of Dex for 2,3 and $5 \mathrm{~h}$. Results are shown as mean \pm SEM from three independent experiments. ${ }^{*} \mathrm{p} \leq$ 0.008 .

by an oxidative stress. In fact, several studies have suggested that PPD induced apoptosis could be mediated by ROS production (Mathur et al., 2005; Chen et al., 2006; Elyoussoufi et al., 2012). Also, it has been demonstrated extensively that ROS play an important role in controlling the neutrophils life span (ScheelToellner et al., 2004a, b). However, the impact of PPD on the ROS pathway in neutrophils has not been studied yet. Therefore, we next studied the effect of PPD in the oxidoredox systems of the human neutrophils.

Oxidation reactions by ROS are regarded as a trigger of the oxidative stress. Several enzymes like SOD, GR and CAT serve as protective antioxidants against oxidative stress (Kuwabara et al., 2008). In this work, we detected an enhanced activity of GR in supernatants of neutrophil lysates when cells were treated with PPD. This increase of GR activity can be explained by the ability of this enzyme to regenerate (GSH) from (GSSG). It is known that oxidative stress results in oxidation of $\mathrm{GSH}$, leading to the formation of GSSG and subsequent formation of mixed disulfides between GSH and the cysteines of several proteins (Fratelli et al., 2003). Moreover, the level of reducing agents, such as GSH, is important in regulating the oxidative intracellular state. In the present study, PPD seems to markedly enhance both SOD and CAT activities at $5 \mathrm{~h}$ of treatment. In addition, Picardo et al. $(1990,1996)$ have found that at noncytotoxic concentrations, PPD induces a transient increase of SOD and CAT, a significant decrease in membrane polyunsaturated fatty acid and production of hydrogen peroxide, and superoxide, on keratinocytes.

In this paper, we have demonstrated that PPD induced an increase of MDA level. We know that MDA can be used to estimate the lipid peroxidation level. Indeed, it is widely accepted that lipid peroxidation is increased by ROS (Sander et al., 2003). ROS are considered to cause damage to cells by oxidizing lipids in the cell membrane or by attacking DNA directly (Inoue et al., 1994). Lipid peroxidation affects the physical stability of the membranes, resulting in altered calcium homeostasis, activation of endonucleases and oxidative damage to DNA, and sulfhydryl modification of proteins (Hedley and 
Chow, 1994; Sandstrom et al., 1995). The increase in lipid peroxidation induced by PPD observed here support the concept that ROS are involved in PPD induced apoptosis. This finding is in concert with those of Mathur et al. (2005) and Chen et al. (2006) which demonstrate a role of ROS in PPD induced apoptosis in keratinocytes and in SV-40 cells. Recent results showed that the use of vitamins $E$ and $C$ inhibited the ROS generation and DNA damage in MDCK cells after treatment with PPD (Chen et al., 2010).

It is believable that ROS generation may change the redox status of cells with subsequent effects on specific kinases, phosphatases and transcription factors which could affect the sensitivity of the cell to apoptotic stimuli (Gardai et al., 2002; Alvarez-Maqueda et al., 2004). Sacktor et al. (2004) have suggested that ROS can attack membrane lipid, proteins and deoxynucleic acids resulting in cellular dysfunction and cell death.

Although PPD induced apoptosis in neutrophils in vitro, we are not certain if the processes described here are also responsible for the symptoms observed in vivo after PPD application. It is known that as a first line of defense, neutrophils are recruited rapidly to inflammatory sites, where the expression of their constitutive cell death program can be delayed or accelerated by a number of agents (Keel et al., 1997; Edwards et al., 2004). Neutrophils apoptosis is classically regarded as a form of cell death that will promote resolution of inflammation (Haslett, 1997). Since apoptotic death is not proinflammatory, induction of death by apoptosis rather than necrosis could confer further advantage to intoxication with PPD, limiting further host responses. There is however, evidence of extensive tissue injury in the context of PPD poisoning (Yagi et al., 1991; Motaouakkil et al., 2006). This might arise because of proinflammatory effect of PPD itself (for example, generation of ROS) (Mathur et al., 1990) or of its metabolites such as Bandrowski's base (Krasteva et al., 1993) or because of its overproduction of ROS.

Onset of apoptosis in neutrophils is much more complex than the simple mechanism we have studied here, but the role of oxidative stress proposed here can also account for the PPD induced apoptosis in neutrophil.

\section{Conclusion}

Data presented in this paper suggest that PPD induces apoptosis of human cultured neutrophils via generation of ROS. It may be suggested that increased production of ROS, as reflected by higher level of MDA, could impair neutrophils membrane integrity and could lead to the alterations in neutrophils antioxidant defense system. Further work is needed to explore the relationship between PPD autoxidation and neutrophils apoptosis and to explain how PPD interacts with immune cells.

\section{ACKNOWLEDGMENTS}

We graciously acknowledge the various volunteers from CRTS for their generous blood donations. Authors gratefully would like to thank Hassan II University, CNRST, CRTS and CNTS for the financial support.

\section{REFERENCES}

Aebi H (1984). Catalase in vivo. Methods Enzymol. 105:121-126.

Aeby P, Wyss C, Beck H, Griem P, Scheffler H, Goebel C (2004). Characterization of the sensitizing potential of chemicals by in vitro analysis of dendritic cell activation and skin penetration. J. Investig. Dermatol. 122:1154-1164.

Alvarez-Maqueda M, El Bekay R, Monteseirín J, Alba G, Chacón P, Vega A, Santa María C, Tejedo JR, Martín-Nieto J, Bedoya FJ, Pintado E, Sobrino F (2004). Homocysteine enhances superoxide anion release and NADPH oxidase assembly by human neutrophils. Effects on MAPK activation and neutrophil migration. Atherosclerosis. 172:229-238.

Bradford M (1976). A rapid and sensitive method for the quantitation of microgram quantities of protein utilizing the principle of protein dye binding. Anal. Biochem. 72:248-254.

Chen SC, Chen CH, Chern CL, Hsu LS, Huang YC, Chung KT, Chye SM (2006). p-Phenylenediamine induces p.53-mediated apoptosis in Mardin Darby canine Kidney cells. Toxicol. in Vitro. 20:801-207.

Chen SC, Chen CH, Tioh YL, Zhong PY, Lin YS, Chye SM (2010). Para-phenylenediamine induced DNA damage and apoptosis through oxidative stress and enhanced caspase- 8 and -9 activities in MardinDarby canine kidney cells. Toxicol. in Vitro. 24:1197-1202.

Chye SM, Hseu YC, Liang SH, Chen CH, Chen SC (2008). Single strand DNA breaks in human lymphocytes exposed to paraphenylenediamine and its derivatives. Bull. Environ. Contam. Toxicol. 80:58-62.

Corbett JF, Menkart J (1973). Hair colouring. Cutis. 12:190-193.

Coulter EM, Farrell J, Mathews KL, Maggs JL, Pease CK, Lockley DJ, David A, Basketter B, Park K, Naisbitt DJ (2007). Activation of human dendritic cells by p-phenylenediamine. J. Pharmacol. Exp. Ther. 320:885-92.

Coulter EM, Jenkinson C, Wu Y, Farrell J, Foster B, Smith A, McGuire C, Pease C, Basketter D, King C, Friedmann PS, Pirmohamed M, Park BK, Naisbitt DJ (2008). Activation of T-Cells from Allergic Patients and Volunteers by $\mathrm{p}$-Phenylenediamine and Bandrowski's Base. J. Invest. Dermatol. 128:897-905.

Di Hio C, Polidoro G, Arduini A, Muccini A, Federici G (1983). Glutathion peroxidase, glutathione reductase, glutathione $S$ transferase and gamma-glutamyl transpeptidase activities in the human early pregnancy placenta. Biochem. Med. 29: 143-148.

Doherty DE, Downey G, Worthen GS, Haslett C, Henson PM (1988). Monocyte retention and accumulation in pulmonary inflammation: requirements for neutrophils. Lab. Invest. 59(2): 200-213.

Edwards SW, Derouet M, Howse M, Moots RJ (2004). Regulation of neutrophil apoptosis by Mcl-1. Biochem. Soc. Trans. 32:489-92.

Elyoussoufi Z, Habti N, Motaouakkil S, Cadi R (2012). Paraphenylenediamine induces apoptosis of Murine myeloma cells in a reactive oxygen species dependent mechanism. J. Toxicol. Environ. Health Sci. 4(4):76-84.

Fratelli M, Demol H, Puype M, Casagrande S, Villa P, Eberini I, Vandekerckhove J, Gianazza E, Ghezzi P (2003). Identification of proteins undergoing glutathionylation in oxidatively stressed hepatocytes and hepatoma cells. Proteomics 3:1154-1161.

Freeman BA, Crapo JD (1982). Biology of disease: free radicals and tissue injury. Lab. Invest. 47:412-426. 
Gardai S, Whitlock BB, Helgason C, Ambruso D, Fadok V, Bratton D, Henson PM (2002). Activation of SHIP by NADPH oxidase-stimulated Lyn leads to enhanced apoptosis in neutrophils. J. Biol. Chem. 277:5236-5246.

Hansen J, Mollgaard B, Avnstorp C, Menne T (1993). Paraben contact allergy: Patch testing and in vitro absorption/metabolism. Am. J. Contact Dermat. 4:78-86.

Haslett C (1997). Granulocyte apoptosis and inflammatory disease. Br. Med. Bull. 53(3): 669-683.

Hedley DW, Chow S (1994). Evaluation of methods for measuring cellular glutathione content using flow cytometry. Cytometry 15:349358.

Huang YC, Hung WC, Kang WY, Chen WT, Chai CY (2007). pPhenylenediamine induced DNA damage in SV-40 immortalized human uroepithelial cells and expression of mutant p53 and COX-2 proteins. Toxicol. Lett. 170:116-123.

Inoue M, Suzuki R, Koide T, Sakaguchi N, Ogiraha Y, Yabu Y (1994). Antioxidant, gallic acid induces apoptosis in HL-60RG cells. Biochem. Biophys. Res. Commun. 204:898-904.

Keel M, Ungethum U, Steckholzer U, Niederer E, Hartung T, Trentz O, Ertel W (1997). Interleukin-10 counterregulates proinflammatory cytokine-induced inhibition of neutrophil apoptosis during severe sepsis. Blood 90:3356-3363.

Kligman AM (1966). The identification of contact allergens by human assay. II. Factors influencing the induction and measurement of allergic contact dermatitis. J. Invest. Dermatol. 47:375-92.

Krasteva M, Nicolas JF, Chabeau G, Garrigue JL, Bour H, Thivolet J and Schmitt D (1993). Dissociation of allergenic and immunogenic functions in contact sensitivity to para-phenylenediamine. Int. Arch. Allergy Immunol. 102:200-204.

Kuwabara M, Asanuma T, Niwa K, Inanami O (2008). Regulation of Cell Survival and Death Signals Induced by Oxidative Stress. J. Clin. Biochem. Nutr. 43(2):51-57.

Lee MW, Park SC, Yang YG, Yim SO, Chae HS, Bach JH, Lee HJ, Kim KY, Lee WB, Kim SS (2002). The involvement of reactive oxygen species (ROS) and p38 mitogen-activated protein (MAP) kinase in TRAIL/Apo2L-induced apoptosis. FEBS Lett. 512:313-318.

Marzulli FN, Maibach HI (1974). The use of graded concentrations in studying skin sensitizers: experimental contact sensitization in man. Food Cosmet. Toxicol. 12:219-27.

Mathur AK, Gupta BN, Narang S, Singh S, Mathur N, Singh A, Shukla LJ, Shanker R (1990). Biochemical and histopathological changes following dermal exposure to paraphenylene diamine in guinea pigs. J. Appl. Toxicol. 10:383-386.

Mathur AK, Raizada RB, Srivastava MK, Singh A (2005). Effect of Dermal Exposure to Paraphenylenediamine and Linear Alkylbenzene Sulphonate in Guinea Pigs. Biomed. Environ. Sci. 18:238-240.

Mattia CJ, Adams JD, Bondy SC (1993). Free radical induction in the brain and liver by products of toluene catabolism. Biochem. Pharmacol. 46:103-110.

Motaouakkil S, Charra B, Hachimi A, Ezzouine $H$, Guedari $H$, Nejmi $H$, Benslama A (2006). Rhabodomyolysis and paraphenylenediamine poisoning. Ann. Fr. Anesth. Reanim. 25:708-713.

Paoletti F, Aldinucci D, Mocali A Carparrini A (1986). A sensitive spectrophotometric method for the determination of superoxide dismutase in tissue extracts. Anal. Biochem. 154:526-541.

Picardo M, Cannistraci C, Cristaudo A, De Luca C, and Santucci B (1990). Study on cross-reactivity to the para group. Dermatologica 181:104-108.
Picardo M, Zompetta C, Grandinetti M, Ameglio F, Santucci B, Faggioni A, Passi S (1996). Paraphenylene diamine, a contact allergen, induces oxidative stress in normal human keratinocytes in culture. Br. J. Dermatol. 134(4):681-685.

Sacktor N, Haughey N, Cutler R, Tamara A, Turchan J, Pardo C, Vargas D, Nath A (2004). Novel markers of oxidative stress in actively progressive HIV dementia. J. Neuroimmunol. 157:176-184.

Samokyszyn VM, Marnett LJ (1990). Inhibition of liver microsomal lipid peroxidation by 13-cis retinoic acid. Free Radic. Biol. Med. 8:491496.

Sander CS, Hamm F, Elsner P, Thiele JJ (2003). Oxidative stress in malignant melanoma and non-melanoma skin cancer. $\mathrm{Br} . \mathrm{J}$. Dermatol. 148 (5):913-922.

Sandstrom PA, Pardi D, Tebbey PW, Dudek RW, Terrian DM, Folks TM, Buttke TM (1995). Lipid hydroperoxide-induced apoptosis: lack of inhibition by Bcl-2 over-expression. FEBS Lett. 365:66-70.

Sax NJ (1984). General chemicals. In: Dangerous Properties of Industrial Materials. Van Nostrand, Reinhold, New York, 6th Edn, p. 2148.

Scheel-Toellner D,Wang KQ,Webb PR, Wong SH, Craddock R, Assi LK, Salmon M, Lord JM (2004a). Early events in spontaneous neutrophil apoptosis. Biochem. Soc. Trans. 32:461-464.

Scheel-Toellner D, Wang K, Craddock R, Webb PR, McGettrick HM, Assi LK, Parkes N, Clough LE, Gulbins E, Salmon M, Lord JM (2004b). Reactive oxygen species limit neutrophil life span by activating death receptor signaling. Blood 104: 2557-2564.

Smith Pease CK (2003). From xenobiotic chemistry and metabolism to better prediction and risk assessment of skin allergy. Toxicol. 192:122.

Warbrick EV, Dearman RJ, Lea LJ, Basketter DA, Kimber I (1999). Local lymph node assay responses to paraphenylenediamine: intraand interlaboratory evaluations. J. Appl. Toxicol. 19:255-260.

Ward PA, Warren JS, Johnson KJ (1988). Oxygen radicals, inflammation, and tissue injury. Free Rod. Biol. Med. 5:403-408.

Wedmore CV, Williams TJ (1981). Control of vascular permeability by polymorphonuclear leukocytes in inflammation. Nature (Lond.) 289:646-650.

White JM, Kullavanijaya P, Duangdeeden I, Zazzeroni R, Gilmour NJ, Basketter DA, McFadden JP (2006). p-Phenylenediamine allergy: the role of Bandrowski's base. Clin. Exp. Allergy 36:1289-1293.

Wyllie AH (1980). Glucocorticoid-induced thymocyte apoptosis is associated with endogenous endonuclease activation. Nature (Lond.) 284:555-556.

Yagi HI, El Hindi AM, Khalil SI (1991). Acute poisoning from hair dye. East Afr. Med. J. 68:404-411. 